THE JOURNAL OF

THORAGIG AND

GARDIOVASCULAR

SURGERY

Vol. 136, No. 1, July 2008

\title{
New developments in the Journal
}

Lawrence H. Cohn, MD

From the Division of Cardiac Surgery, Brigham and Women's Hospital, Harvard Medical School.

Address for reprints: Lawrence H. Cohn, MD, 75 Francis St, Boston, MA 02115 (E-mail: 1cohn@partners.org).

J Thorac Cardiovasc Surg 2008;136:1-3

0022-5223/\$34.00

Copyright $\odot 2008$ by The American Association for Thoracic Surgery

doi:10.1016/j.jtcvs.2008.05.003

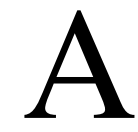

s the second volume of 2008 begins, I would like to share some thoughts, some new features, and more contemplations.

In this issue, there is a summary of the proceedings of the American College of Cardiology, an important meeting with an impact on cardiovascular surgeons. Although there is surgical input to this meeting, most practicing cardiovascular surgeons rarely recognize the important context of this meeting and what our cardiology colleagues are thinking. Drs Fred Resnic and Akshay Desai from the Division of Cardiovascular Medicine at the Brigham and Women's Hospital have concisely summarized the topics of this meeting that pertain to the practice of cardiovascular medicine and surgery. We plan to continue to summarize the proceedings of other important meetings affecting cardiovascular and thoracic surgeons and believe that these summaries will keep us up to date with what our colleagues in the cardiovascular and thoracic service line are currently accomplishing and thinking. If you have any comments about this concept or other important meetings you might like summarized, please let us know.

Another new feature being introduced is Expert Commentary. These articles are written by recognized experts totally immersed in the various fields who are invited to give their valued opinions and provide us all with a current overview. We have already published comments on surgical simulation and cardiac research, as well as a piece by the Lasker Awardee, Dr Albert Starr.

As stated in my initial editorial, we are working toward the concept of the cardiothoracic service line and have taken some steps in this direction. This is reflected in our current Editorial Board, which has now been expanded to include cardiac anesthesiologists, critical care physicians, and cardiac perfusionists. I believe that this inclusiveness will become increasingly important as more institutions worldwide develop the service line concept, blending all specialists related to the delivery of cardiovascular medicine. There have also been some style changes for easier reading, allowing us more pages for editorial content. This new interior format will begin to appear in the coming months. We continue to make headway related to continuing medical education through CTSNet (http://ctsnet.org). We plan in the near future to highlight short videos on the CTSNet website accompanying articles that describe operative procedures, allowing the reader to watch a video while reading the corresponding article. We believe that this will amplify the learning process by correlating visualization of operative procedures with important clinical data to underscore the validity or lack thereof of specific operative approaches.

In this issue, we also introduce our Associate Editors and current Editorial Board. I thank them for their support and assistance this past 6 months. 


\section{Journal of Thoracic and Cardiovascular Surgery}

\section{Editorial Staff}

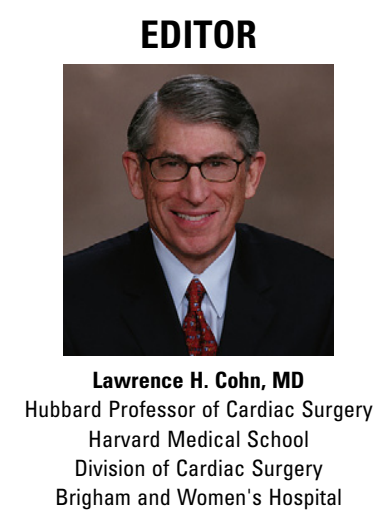

ASSOCIATE EDITOR CONGENTIAL HEART DISEASE

Pedro J. del Nido, MD

William E. Ladd Professor of Child Surgery Harvard Medical School

Chairman, Department of Cardiac Surgery Children's Hospital Boston

\section{ASSOCIATE EDITOR CARDIOPULMONARY SUPPORT AND PHYSIOLOGY, EVOLVING TECHNOLOGY}

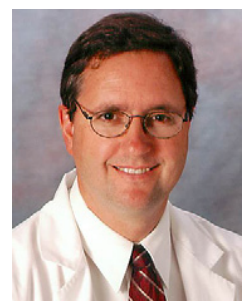

Frank W. Sellke, MD Johnson \& Johnson Professor of Surgery Harvard Medical School

Chief of Cardiothoracic Surgery Research Beth Israel Deaconess Medical Center

\section{ASSOCIATE EDITOR} GENERAL THORACIC SURGERY

Thomas W. Rice, MD

Daniel \& Karen Lee Chair in Thoracic Surgery Head, Section of General Thoracic Surgery

Professor of Surgery Cleveland Clinic

Lerner College of Medicine Case Western Reserve University

\section{ASSOCIATE EDITOR ANESTHESIA AND CRITICAL CARE}

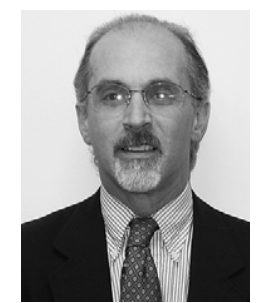

Stanton K. Shernan, MD, FAHA, FASE Associate Professor of Anesthesia Harvard Medical School Brigham and Women's Hospital
Chief, Division of Cardiac Anesthesia

\section{ASSOCIATE EDITOR ACQUIRED CARDIOVASCULAR DISEASE}

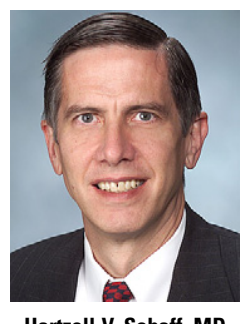

Hartzell V. Schaff, MD Stuart W. Harrington Professor of Surgery Chair, Division of Cardiovascular Surgery Mayo Clinic College of Medicine

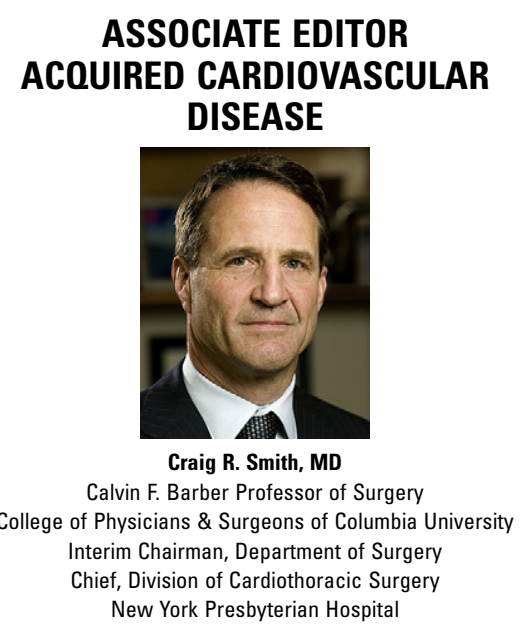


STATISTICS EDITOR

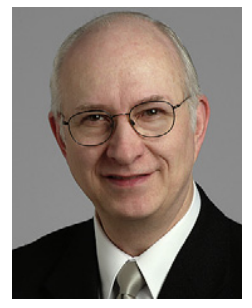

Eugene H. Blackstone, MD

Director, Clinical Research

Thoracic and Cardiovascular Surgery Cleveland Clinic

\section{E-EDITOR}

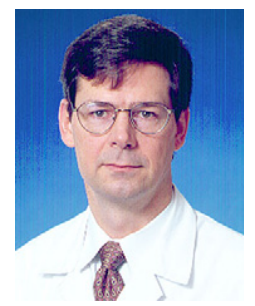

Bryan Meyers, MD

Professor of Surgery

Washington University School of Medicine Chief, Section of Thoracic Surgery

Barnes-Jewish Hospital
ETHICS EDITOR

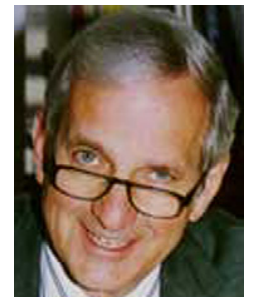

Martin McKneally MD, PhD Professor Emeritus

Department of Surgery and Joint Centre for Bioethics University of Toronto

Senior Thoracic Surgeon

Toronto General Hospital

\section{MANAGING EDITOR}

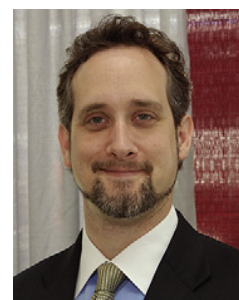

Ryan Walther, MA

Managing Editor

AATS Scientific Publications American Assocation for

Thoracic Surgery 